\title{
PENGARUH DEWAN KOMISARIS, LEVERAGE, DAN STRUKTUR KEPEMILIKAN TERHADAP PENGUNGKAPAN ENTERPRISE RISK MANAGEMENT (ERM)
}

\author{
Jetmi Ade Cecasmi ${ }^{1)}$ \\ Samin $^{2)}$ \\ Universitas Pembangunan Nasional "Veteran" Jakarta ${ }^{1,2)}$
}

\begin{abstract}
The purpose of this study was to examine the influence of Board of Commissioner, Leverage, and Ownership Structure on the Enterprise Risk Management disclosure of banking firm listed in Indonesian Stock Exchange for the period from 2013 to 2015. Sampling technique using purposive sampling (purposive sampling method). The sampel used in this study is a banking company that meets the criteriaas set out in this study to obtain 21 banking. The data obtained derived from the annual report and financial report of the banks publishe. The analysis technique used in this research is multiple linear regression to test the classical assumption first. The result showed that the Board of Commissioner have a significant influence on the Enterprise Risk Management Disclosure. Leverageand Ownership Structure is not significantly effects on Enterprise Risk Management Disclosure.

Keywords: Enterprise Risk Management Disclosure, Board of Commissioner, Leverage, Ownership Structure
\end{abstract}

\section{PENDAHULUAN}

Risiko merupakan penghambat pencapaian suatu tujuan perusahaan. Setiap risiko yang akan terjadi di masa yang akan datang tentu tidak bisa dihindari oleh perusahaan. Berdasarkan Peraturan Bank Indonesai Nomor: 11/25/PBI/2009 tentang Perubahan atas Peraturan Bank Indonesia Nomor: 5/8/PBI/2003 tentang Penerapan Manajemen Risko Bagi Bank Umum menyatakan bahwa risiko yang dihadapi oleh perbankan meliputi risiko kredit, risiko pasar, risiko likuiditas, risiko operasional, risiko hukum, risiko reputasi, risiko stratejik, dan risiko kepatuhan. Risiko-risiko tersebut mengindikasikan pentingnya menentukan suatu strategi dalam mengantisipasi risiko demi keberlangsungan dan tercapainya tujuan perusahaan. Penerapan manajemen risiko tersebut erat kaitannya dengan pelaksanaan good corporate governance, yaitu prinsip transparansi yang menuntut diterapkannya Enterprise Risk Management (Meizaroh \& Lucyanda, 2011).

Keberadaan risiko dalam setiap kegiatan usaha, mendorong perusahaan untuk melakukan pengelolaan risiko yang efektif. Hal ini dilakukan untuk mengurangi kerugian yang terjadi pada perusahaan dan investor (Prayoga \& Almilia, 2013). Pengungkapan risiko oleh perusahaan sangat berguna bagi para stakeholder untuk pengambilan keputusan dalam menanamkan saham. Pengungkapan risiko juga merupakan salah satu cara perusahaan untuk berkomunikasi dengan para stakeholdernya. Melalui pengungkapan risiko, perusahaan dapat memberikan informasi mengenai risiko yang terjadi diperusahaan. Luas pengungkapan manajemen risiko menunjukan kemampuan sebuah perusahaan dalam mengelola manajemen risikonya dan membuktikan bahwa perusahaan berusaha untuk memuaskan kebutuhan akan informasi yang dibutuhkan oleh para stakeholder (Kumalasari, 2014).

Dalam kasus perusahaan Bank BNI dan Bank Syariah Mandiri yang terdapat risiko operasional dimana mengalami kredit fiktif yang menimbulkan kredit macet. 
Pada media Okezone.com yang diakses pada tanggal 19 Februari 2014 oleh F Anggiawan, perusahaan Bank Syariah Mandiri menyalurkan kredit fiktif sebesar Rp. 102 Milyar kepada 197 debitur fiktif. Akibatnya Bank Syariah Mandiri berpotensi mengalami kerugian sebesar Rp. 59 Milyar. Bermula dari pengajuan kredit seorang pengusaha properti bernama Iyan Permana tahun 2011 senilai Rp. 1 Milyar. Namun dalam proses pengajuannya, Iyan dan tiga pegawai Bank Syariah Mandiri melakukan penyimpangan kredit, mereka kemudian membuat nasabah, memanipulasi sejumlah dokumen dan tidak menjalani prosedur perbankan yang seharusnya dalam mengajukan kredit.

Di tahun yang sama, pada media Liputan6.com yang diakses pada tanggal 12 September 2014 oleh M Syukur, perusahaan Bank BNI pada tahun 2007 melakukan pencairan sebesar Rp. 17 miliar, sehingga mengakibatkan terjadinya kerugian negara sebesar Rp. 14.445 juta dan tahun 2008 terdapat pencairan sebesar Rp. 23 miliar, yang kemudian menimbulkan kerugian negara lagi sebesar Rp. 22.650 juta. Total kerugian negara mencapai Rp. 37 miliar lebih. Berawal dari PT Barito Riau Jaya yang mengajukan kredit Rp 40 miliar ke BNI 46. Sebagai agunan, Esron melampirkan beberapa surat tanah di Kabupaten Kampar. Tanpa tinjauan di lapangan, pegawai Bank BNI menyetujui kredit. Hasil penyelidikan, sebagian tanah yang diagunkan tidak ada.

Dari kasus Bank Syariah Mandiri dan Bank BNI tersebut, membuktikan bahwa manajemen risiko perusahaan atau Enterprise Risk Management (ERM) merupakan strategi yang dibutuhkan perusahaan untuk mengevaluasi dan mengelola serta membantu menemukan jalan keluar yang tepat dalam setiap risiko yang muncul (Meizaroh \& Lucyanda, 2011).

Beberapa penelitian terdahulu telah meneliti mengenai faktor - faktor yang mempengaruhi pengungkapan Enterprise Risk Management. Namun, terdapat hasil yang tidak konsisten seperti pada hasil penelitian dari Meizaroh \& Lucyanda (2011) pada variabel Dewan Komisaris menunjukkan hasil yang tidak signifikan terhadap pengungkapan Enterprise Risk Management namun berbeda dengan hasil penelitian Jatiningrum \& Fauzi (2012), dan Husaini, dkk (2013) yang menunjukkan hasil yang signifikan terhadap pengungkapan Enterprise Risk Management.

Hasil penelitian dari Syifa (2013) pada variabel Leverage menunjukkan hasil yang tidak signifikan terhadap pengungkapan Enterprise Risk Management namun berbeda dengan hasil penelitian Onder \& Ergin (2012) dan Marhaeni \& Yanto (2015) yang menunjukkan hasil yang signifikan terhadap pengungkapan Enterprise Risk Management.

Hasil penelitian dari Ashuri, Nia, \& Asadpour (2014) pada variabel Struktur Kepemilikan menunjukkan hasil yang tidak signifikan terhadap pengungkapan Enterprise Risk Management, sedangkan hasil penelitian Syifa (2013), dengan Sari (2013) menunjukkan hasil yang signifikan terhadap pengungkapan Enterprise Risk Management.

Penelitian ini berbeda dengan penelitian sebelumnya dalam beberapa hal. Pertama, variabel

yang digunakkan dalam penelitian ini adalah Dewan Komisaris, Leverage, Struktur Kepemilikan. Sedangkan pada penelitian Meizaroh \& Lucyanda (2011) menggunakan variabel Komisaris Independen, Ukuran Dewan Komisaris, Keberadaan Risk Management Committee, Reputasi Auditor, dan Konsentrasi Kepemilikan. Kedua, penelitian ini menggunakan periode penelitain tahun 2013-2015. Sedangkan pada penelitian Meizaroh \& Lucyanda (2011) menggunakan periode penelitian 2009. Ketiga, 
penelitian ini menggunakan sampel perusahaan perbankan yang terdaftar di BEI. Sedangkan pada penelitain Meizaroh \& Lucyanda (2011) menggunakan sampel perusahaan manufaktur yang terdaftar di BEI.

Berdasarkan fenomena dan gap research tersebu, maka dapat dirumuskan masalah sebagai berikut "Apakah Dewan Komisaris, Leverage, dan Struktur Kepemilikan berpengaruh signifikan terhadap Pengungkapan Enterprise Risk Management"

\section{TINJAUAN PUSTAKA}

\section{Teori Keagenan (Agency Theory)}

Dalam menjalankan sebuah bisnis, biasanya dapat terjadi sebuah konflik, baik konflik dengan pihak eksternal maupun pihak internal. Konflik kepentingan yang dimungkinkan terjadi karena adanya keadaan asimetri informasi. Pihak principal berkepentingan agar perusahaan memiliki risiko seminimal mungkin sedangkan pihak agent berkepentingan untuk mendapatkan penilaian yang baik dari principal (Sari, 2013).

Teori Keagenan (Agency Theory) menyebutkan bahwa perusahaan adalah tempat atau intersection point bagi hubungan kontrak yang terjadi antara manajemen, pemilik, kreditor, dan pemerintah (Harahap, 2012).

Menurut Meizaroh \& Lucyanda (2011) menyatakan bahwa teori keagenan (agency theory) mengusulkan serangkaian mekanisme untuk menyatukan kepentingan pemegang saham dan manajer seperti adanya mekanisme pengawasan internal oleh dewan komisaris dan komite audit, pemegang saham mayoritas, adanya pengendalian internal, serta pengawasan eksternal yang dilakukan eksternal auditor atas laporan keuangan perusahaan.

Berdasarkan teori agensi, dewan komisaris dianggap sebagai mekanisme pengendalian intern tertinggi, yang bertanggung jawab untuk memonitor tindakan manajemen puncak (Rusdianto 2013, hlm. 46).

\section{Teori Sinyal (Signalling Theory)}

Salah satu teori yang melatarbelakangi masalah asimetri informasi adalah signalling theory. Ketika digunakan dalam praktek pengungkapan perusahaan, signaliing theory secara umum menguntungkan bagi perusahaan dalam praktek corporate governance yang baik (Andarini \& Januarti, 2010).

Menurut Houston \& Brigham (2011, hlm. 186) menjelaskan bahwa 'Sinyal merupakan suatu tindakan yang diambil oleh manajemen suatu perusahaan untuk memberikan petunjuk kepada investor tantang bagimana manajemen menilai prospek perusahaan tersebut'. Dikarenakan pihak manajer lebih mengetahui informasi perusahaan lebih baik dibandingkan dengan investor atau pengguna laporan keuangan. Oleh karena itu, sudah menjadi kewajiban manajemen untuk memberikan sinyal berupa informasi mengenai perusahaan kepada stakeholder (Godfrey 2010, hlm. 376).

Salah satu sinyal perusahaan dalam pelaksanaan corporate governance adalah penerapan dan pengungkapan Enterprise Risk Management dalam laporan tahunan perusahaaan. Hal ini memberikan informasi bahwa perusahaan tersebut lebih baik dibandingkan perusahaan lain karena telah menerapkan prinsip transparansi (Meizaroh \& Lucyanda, 2011).

Berdasarkan uraian di atas dapat disimpulkan bahwa dari pengungkapan Enterprise Risk Management memberikan sinyal kepada pemegang saham bahwa 
perusahaan tersebut lebih baik karna telah menerapkan manajemen risiko di dalam perusahaannya. mengenai risiko yang terjadi di perusahaan.

$$
\mathrm{ERM}=\frac{\begin{array}{c}
\text { Jumlah Item yang Diungkapkan } \\
\text { Perusahaan }
\end{array}}{108}
$$

\section{Enterprise Risk Management (ERM)}

Enterprise Risk Management berdasarkan Committee of Sponsoring Organization of the Treadway Commision (2004) yaitu :

Sebuah proses yang dipengaruhi oleh jajaran direktur entitas, manajemen dan personil lain, yang diterapkan dalam penentuan strategi dalam perusahaan, didesain untuk mengidentifikasi kemungkinan - kemungkinan yang potensial yang mungkin mempengaruhi entitas, dan mengelola resiko - resiko dan kecenderungan resiko yang mungkin terjadi, untuk menyediakan jaminan yang layak mengenai pencapaian tujuan perusahaan.

Perhitungan item - item menggunakan pendekatan dikotomi yaitu setiap item ERM yang diungkapkan diberi nilai 1 , dan nilai 0 apabila tidak diungkapkan. Setiap item akan dijumlahkan untuk memperoleh keseluruhan indeks ERM masing - masing perusahaan. Informasi mengenai pengungkapan ERM diperoleh dari laporan tahunan (annual report) dan situs perusahaan (Meizaroh \& Lucyanda, 2011). Skala yang digunakan adalah skala rasio. Dengan persamaan sebagai berikut:

Rasio ini menggambarkan seberapa besar tingkat item yang telah diungkapkan mengenai penerapan manajemen risiko di suatu perusahaan. Semakin besar nilai rasio maka semakin baik karena perusahaan telah sadar akan risiko yang akan dihadapi dan semakin transparan informasi yang diberikan mengenai manajemen risiko diperusahaannya.

\section{Dewan Komisaris}

Pada Pasal 1 Ayat 6 Undang - Undang Republik Indonesia Nomor 40 Tahun 2007 yang mengatur tentang Perseroan Terbatas menyatakan Dewan Komisaris adalah Organ Perseroan yang bertugas melakukan pengawasan secara umum dan/ atau khusus sesuai dengan anggaran dasar serta memberi nasihat kepada direksi. Pengukuran terhadap Dewan Komisaris diukur dengan menghitung jumlah anggota Dewan Komisaris yang dimiliki perusahaan setiap satu tahun. Skala yang digunakan adalah skala rasio. dengan jumlah anggota Dewan Komisaris yang besar menambah peluang untuk saling bertukar informasi dan keahlian guna memberikan pengawasan yang efektif mengenai manajemen risiko perusahaan, sehingga dapat meningkatkan kualitas Enterprise Risk Management. Selain itu, banyaknya jumlah rapat yang dilakukan oleh dewan komisaris dapat mendorong perusahaan untuk lebih luas dalam mengidentifikasi risiko yang mungkin akan dihadapi oleh perusahaan kemudian dewan komisaris dapat mendiskusikannya bersama komite menejemen risiko untuk mencari solusi dalam memitigasi risiko tersebut.

\section{Leverage}

Menurut Kasmir (2011, hlm. 151) menyatakan bahwa 'Leverage merupakan seberapa besar beban hutang yang ditanggung perusahaan dibandingkan dengan asetnya'. Pengukuran terhadap leverage diukur dengan membandingkan total hutang 
dengan total aset. Skala yang digunakan adalah skala rasio. Dengan persamaan sebagai berikut:

$$
\text { Debt to asset ratio }=\frac{\text { Total debt }}{\text { Total assets }}
$$

Semakin tinggi tingkat leverage artinya pendanaan dengan utang semakin banyak, maka semakin sulit bagi perusahaan untuk memperoleh tambahan pinjaman karena dikhawatirkan perusahaan tidak dapat mampu menutupi utang - utangnya dengan aktiva yang dimilikinya.

\section{Struktur Kepemilikan}

Menurut Ardiansyah \& Adnan (2014) menyatakan bahwa 'Struktur Kepemilikan adalah komposisi kepemilikan saham yang berasal dari pihak internal maupun pihak eksternal yang bersama - sama dalam memajukan perusahaan. Pengukuran terhadap Struktur Kepemilikan diukur dengan membandingkan jumlah kepemilikan saham terbesar dengan total saham perusahaan dikalikan dengan seratus persen. Skala yang digunakan adalah skala rasio. Dengan persamaan sebagai berikut:

$$
\begin{array}{lcr}
\text { Konsentrasi } & \text { Jumlah Kepemilikan Saham } & \text { X } \\
\text { Kepemilikan }= & \text { Terbesar } & 100 \%
\end{array}
$$

Semakin besar presentase kepemilikan yang dimiliki oleh perusahaan maka akan semakin baik artinya perusahaan pada periode tersebut memiliki hak yang besar pula dalam memperoleh informasi dan memegang kendali yang besar atas aktivitas bisnis perusahaan tempat mereka investasi.

\section{Kerangka Model Penelitian}

Berdasarkan dari penjelasan yang telah dikemukakan sebelumnya, maka dapat digambarkan kerangka penelitian sebagai berikut.

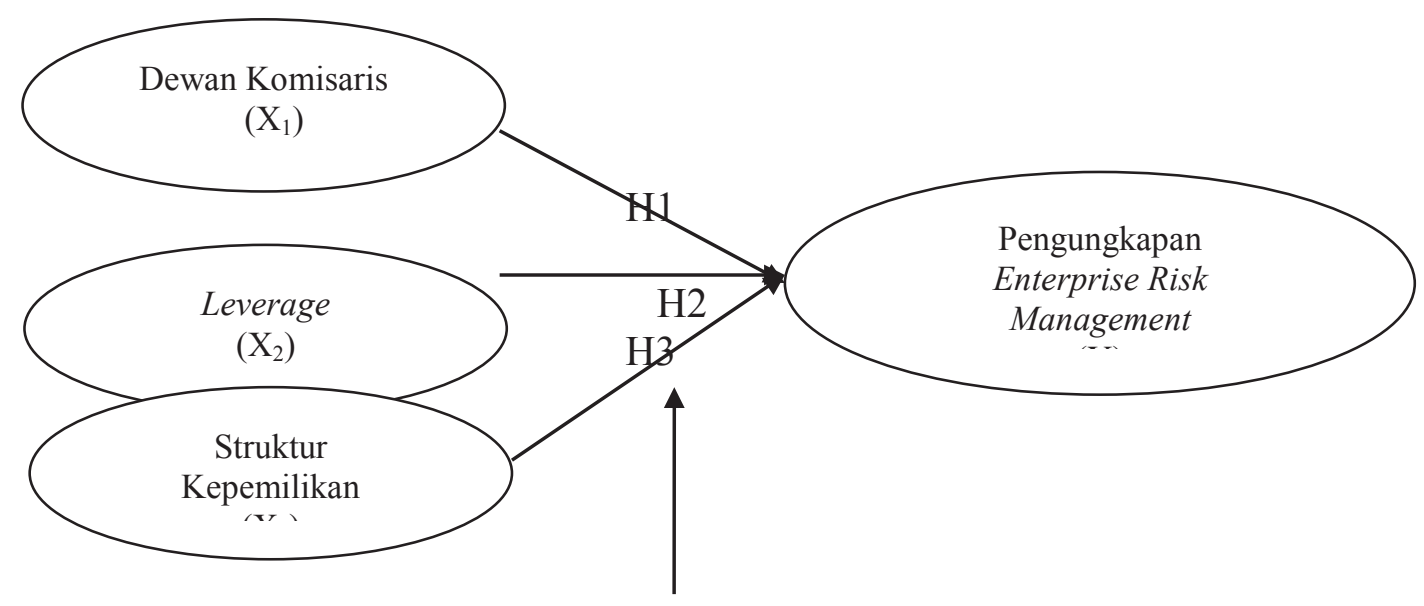

Uji Regresi Berganda

\section{Hipotesis Penelitian}

Dari rumusan masalah dan kerangka model penelitian diatas, maka hipotesis dalam penelitian ini dapat dirumuskan sebagai berikut : Dewan Komisaris, Leverage, dan 
Struktur Kepemilikan berpengaruh signifikan terhadap Pengungkapan Enterprise Risk Management.

\section{METODE PENELITIAN}

\section{Populasi dan Sampel}

Sampel yang digunakan dalam penelitian ini adalah perusahaan perbankan yang terdaftar di Bursa Efek Indonesia (BEI) dari periode tahun 2013 sampai dengan tahun 2015. Pengambilan sampel menggunakan metode purposive sampling, yaitu penentuan sampel berdasarkan kriteria tertentu sesuai yang dikehendaki oleh peneliti. Adapun kriteria - kriteria yang dipilih dalam penentuan sampel adalah:

a. Perusahaan perbankan yang terdaftar di Bursa Efek Indonesia dan telah menerbitkan laporan keuangan tahunan (annual report) yang sudah di audit dari tahun $2013-2015$.

b. Perusahaan perbankan yang telah menerapkan manajemen risiko dalam laporan tahunan secara konsisten dari tahun 2013 - 2015.

c. Perusahaan perbankan yang memiliki kelengkapan data mengenai Dewan Komisaris, Leverage, dan Struktur Kepemilikan.

d. Perusahaan perbankan yang terkonsentrasi kepemilikan sahamnya $\geq 50 \%$ pada tahun $2013-2015$

\section{Jenis Data}

Penelitian ini menggunakan data sekunder, yaitu data yang diperoleh dari pihak lain atau tidak langsung dari sumber utama (perusahaan), berupa publikasi dalam kurun waktu tiga tahun. Data tersebut berupa laporan keuangan tahunan (annual report) dan laporan keuangan (financial report) dari perusahaan perbankan yang terdaftar di Bursa Efek Indonesia periode tahun $2013-2015$.

\section{Sumber Data}

Seluruh data bersumber dari laporan keuangan tahunan (annual report) dan laporan keuangan (financial report) perusahaan perbankan periode tahun 2013 - 2015 yang telah dipublikasikan di website Bursa Efek Indonesia (BEI) www.idx.co.id dan website perusahaan terkait.

\section{Teknik Analisis}

Teknik analisis data yang digunakan dalam penelitian ini menggunakan analisis regresi linier berganda, yaitu analisis untuk mengukur besarnya pengaruh antara Dewan Komisaris, Leverage, dan Struktur Kepemilikan terhadap Pengungkapan Enterprise Risk Management maka digunakan metode regresi linier berganda. Untuk mempermudah melakukan perhitungan, penelitian ini menggunakan alat bantu SPSS (Statistical Product and Service Solution) versi 21 dan Microsoft Excel 2010.

\section{Statistik Deskriptif}

Statistik deskriptif memberikan gambaran atau deskriptif suatu data dilihat dari nilai rata - rata (mean), nilai tertinggi (maksimum), nilai terendah (minimum), dan deviasi standar (Ghozali 2013, hlm. 19). 


\section{Pengujian Hipotesis}

\section{Uji Statistik F (Uji Signifikansi Simultan)}

'Uji F digunakan untuk menguji pengaruh variabel independen secara bersama - sama terhadap variabel dependen' (Ghozali 2013, hlm. 98).

\section{Uji Statistik t (Uji Signifikansi Parameter Individual)}

'Uji Statistik t dilakukan untuk menguji seberapa jauh suatu variabel independen berpengaruh atau tidak secara individu terhadap variabel dependen' (Ghozali 2013, hlm. 98).

\section{Uji Koefisien Determinan (Adjusted $\boldsymbol{R}^{\mathbf{2}}$ )}

Analisis determinasi (Adjusted $R^{2}$ ) digunakan untuk mengukur saberapa jauh kemampuan variabel independen (Dewan Komisaris, Leverage, dan Struktur Kepemilikan) dalam menjelaskan Variabel dependen (Pengungkapan Enterprise Risk Management) (Ghozali 2013, hlm. 97).

\section{HASIL DAN PEMBAHASAN}

Tabel 11. Statistik Deskriptif Descriptive Statistics

\begin{tabular}{lrrrrr}
\hline & $\mathrm{N}$ & $\begin{array}{c}\text { Minimu } \\
m\end{array}$ & $\begin{array}{c}\text { Maximu } \\
m\end{array}$ & Mean & $\begin{array}{c}\text { Std. } \\
\text { Deviation }\end{array}$ \\
\hline Dewan Komisaris & 63 & 3 & 10 & 5.19 & 2.031 \\
\hline Leverage & 63 & .09934 & .94794 & .8244434 & .16454659 \\
\hline Struktur Kepemilikan & 63 & .51462 & .99999 & .7014188 & .14630359 \\
\hline $\begin{array}{l}\text { Enterprise Risk } \\
\text { Management }\end{array}$ & 63 & .39815 & .83333 & .6788654 & .09340778 \\
\hline Valid N (listwise) & 63 & & & & \\
\hline
\end{tabular}

Sumber: Data diolah dari SPSS 21

Pada tabel 11, menunjukan bahwa variabel dependen yaitu Enterprise Risk Management (Y) pada sampel Perusahaan Perbankan yang terdaftar di Bursa Efek Indonesia periode 2013 sampai dengan 2015 jumlah sampel yang digunakan dalam penelitian ini sebanyak 63 perusahaan dengan nilai maksimum dalam variabel dependen yaitu Enterprise Risk Management adalah sebesar 0.8333 atau 83,33\% yaitu pada perusahaan Bank Mandiri (Persero), Tbk. (BMRI) pada periode 2014, sedangkan nilai minimum adalah sebesar 0,3981 atau 39,81\% yang dimiliki oleh Perusahaan Bank Pan Indonesia Syariah, Tbk. (PNBS) pada periode 2013 Standar deviasi variabel dependen atau Enterprise Risk Management adalah sebesar 0,0934 atau 9,34\%.

Variabel Dewan Komisaris (X1) pada 63 sampel perusahaan perbankan yang terdaftar di Bursa Efek Indonesia (BEI) pada periode 2013 sampai dengan 2015 memiliki nilai maksimum pada variabel Dewan Komisaris adalah sebesar 10 pada perusahaan Bank CIMB Niaga, Tbk. (BNGA) pada periode 2014. Nilai minimum pada variabel Dewan Komisaris sebanyak 3 anggota pada perusahaan Bank Pundi Indonesia, Tbk. (BEKS) dan Bank Sinar Mas, Tbk. (BSIM) untuk periode 2013 sampai dengan periode 2015, Sedangkan standar deviasi pada variabel Dewan Komisaris sebesar 2,031.

Variabel Leverage (X2) pada 63 sampel perusahaan Perbankan yang terdaftar di Bursa Efek Indonesia (BEI) pada periode 2013 sampai dengan 2015 memiliki nilai maksimum pada variabel Leverage adalah sebesar 0,9479 atau 94,79\% pada perusahaan 
Bank Pundi Indonesia, Tbk. (BEKS) pada periode 2015. Nilai minimum pada variabel Leverage sebesar 0,0993 atau 9,93\% pada perusahaan Bank Pan Indonesia Syariah, Tbk (PNBS) pada periode 2013. Nilai standar deviasi pada variabel ini adalah sebesar 0,0350 atau $3,5 \%$.

Variabel Struktur Kepemilikan (X3) pada 63 sampel perusahaan Perbankan yang terdaftar di Bursa Efek Indonesia (BEI) pada periode 2013 sampai dengan periode 2015 memiliki nilai maksimum pada variabel Struktur Kepemilikan adalah sebesar 0,9999 atau 99,99\% pada perusahaan Bank Pan Indonesia Syariah, Tbk (PNBS) pada periode 2013. Nilai minimum pada variabel Struktur Kepemilikan adalah sebesar 0,5146 atau $51,46 \%$ pada perusahaan Bank Pembangunan Daerah Jawa Timur, Tbk. pada periode 2013 sampai dengan periode 2015, Sedangkan nilai standar deviasi pada variabel Struktur Kepemilikan adalah sebesar 0,1038 atau 10,38\%.

\section{Uji Normalitas}

Tabel 12. Uji Normalitas One Sample Kolmogorov-Smirnov One-Sample Kolmogorov-Smirnov Test

\begin{tabular}{|c|c|c|c|c|c|}
\hline & $\begin{array}{l}\text { Dewan } \\
\text { Komisar } \\
\text { is }\end{array}$ & $\begin{array}{c}\text { Leverag } \\
e\end{array}$ & $\begin{array}{c}\text { Struktur } \\
\text { Kepemilika } \\
\text { n }\end{array}$ & $\begin{array}{c}\text { Enterprise } \\
\text { Risk } \\
\text { Management }\end{array}$ & $\begin{array}{l}\text { Unstandardiz } \\
\text { ed Residual }\end{array}$ \\
\hline$N$ & 44 & 44 & 44 & 44 & \\
\hline $\begin{array}{l}\text { Normal Mean } \\
\text { Parameters }^{a}\end{array}$ & 5.57 & $\begin{array}{r}.861703 \\
6 \\
\end{array}$ & .6605416 & .7148569 & .000000 \\
\hline $\begin{array}{ll}\text { Parameters }_{, b} & \text { Std. } \\
& \text { Deviation } \\
\end{array}$ & 1.934 & $\begin{array}{r}.035092 \\
86 \\
\end{array}$ & .10389218 & 2246 & 020 \\
\hline Most & .200 & .078 & .193 & .124 & .11 \\
\hline Extreme & .200 & .076 & .193 & .070 & .06 \\
\hline Differences Negative & -.146 & -.078 & -.099 & -.124 & -.11 \\
\hline Kolmogorov-Smirnov Z & 1.329 & .516 & 1.278 & .825 & .74 \\
\hline Asymp. Sig. (2-tailed) & .058 & .953 & .076 & .505 & $.6 ?$ \\
\hline \multicolumn{6}{|c|}{$\begin{array}{l}\text { a. Test distribution is Normal. } \\
\text { b. Calculated from data. } \\
\text { Sumber: Data yang diolah oleh SPSS } 21 \\
\text { Data ini telah melalui tahap outlier }\end{array}$} \\
\hline \multicolumn{6}{|c|}{$\begin{array}{l}\text { Berdasarkan tabel } 12 \text { di atas terlihat bahwa seluruh variabel sudah berdistribusi } \\
\text { al yang ditunjukkan nilai Asymp. Sig. (2-tailed) pengujian One Sample } \\
\text { ogorov-Smirnov sebesar } 0.637 \text { yang lebih besar dari 0,05. Secara parsial seluruh } \\
\text { oel sudah terdistribusi normal yang ditunjukkan nilai signifikansi pengujian One } \\
\text { le Kolmogorov-Smirnov Dewan Komisaris sebesar } 0,058 \text {, Leverage sebesar 0,953, } \\
\text { tur Kepemilikan sebesar 0,76 dan Enterprise Risk Management sebesar } 0,505 \text { yang } \\
\text { besar dari 0,05. Hal ini berarti bahwa nilai sampel telah terdistribusi dengan } \\
\text { al. Namun selain uji Normalitas One Sample Kolmogorov-Smirnov diatas, uji } \\
\text { tik yang digunakan untuk menguji normalitas residual juga dapat digunakan } \\
\text { an Probability Plot. }\end{array}$} \\
\hline
\end{tabular}




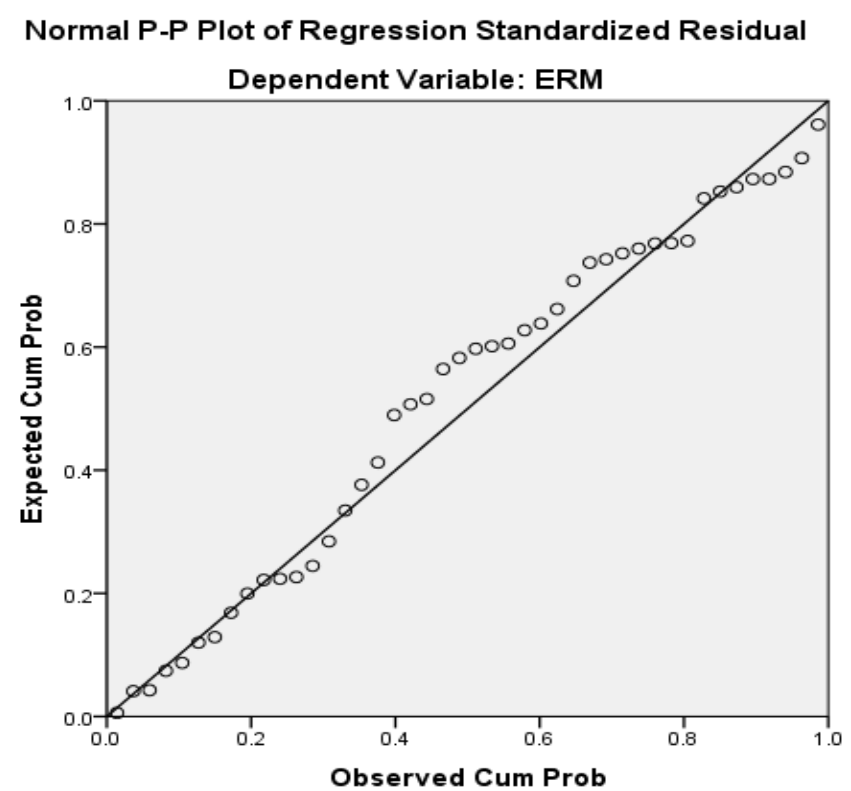

Sumber: Data diolah dari SPSS 21

Data ini sudah melalui tahap outlier

Gambar 3. Normal Probability Plot

Berdasarkan gambar 3 di atas, terlihat titik-titik menyebar disekitar garis diagonal, serta penyebarannya mengikuti arah garis diagonal, maka model regresi memenuhi asumsi normalitas. Sehingga hal ini konsisten dengan analisis menggunakan One Sample Kolmogorov-Smirnov pada pengujian sebelumnya yang menyatakan memenuhi asumsi normalitas.

\section{Uji Multikolinearitas}

Tabel 13. Hasil Uji Multikolinieritas Coefficients $^{a}$

\begin{tabular}{llll}
\hline \multirow{2}{*}{ Model } & \multicolumn{2}{c}{ Collinearity Statistics } \\
\cline { 2 - 4 } & \multicolumn{2}{c}{ Tolerance } & \multicolumn{2}{c}{ VIF } \\
\cline { 2 - 4 } 1 & (Constant) & .908 & 1.101 \\
\cline { 2 - 4 } & Dewan Komisaris & .922 & 1.084 \\
\cline { 2 - 4 } & Leverage & .981 & \multirow{2}{*}{1.019} \\
\cline { 2 - 4 } & Struktur & & \\
& Kepemilikan & &
\end{tabular}

Sumber: Data diolah dari SPSS 21

Data ini sudah melalui tahap outlier

Dari tabel 13 di atas, dapat diketahui bahwa nilai Variance Inflation Factor (VIF) dari masing-masing variabel independen memiliki nilai kurang dari $10(\mathrm{VIF}<10)$ yaitu pada variabel Dewan Komisarisdan nilai Tolerance untuk seluruh variabel independen memiliki nilai lebih dari 0.10.Hasil ini dapat disimpulkan bahwa variabel Dewan Komisaris, Leverage, dan Struktur Kepemilikan tidak saling berhubungan ataupun tidak terkait satu sama lain sehingga model regresi dalam penelitian ini tidak menunjukkan multikolinieritas. 


\section{Uji Autokorelasi}

Tabel 14. Hasil Uji Autokorelasi

Model Summary ${ }^{b}$

\begin{tabular}{l}
\hline Model Durbin-Watson \\
\hline 1 \\
\hline a. Predictors: (Constant), Struktur Kepemilikan, Leverage, \\
Dewan Komisaris \\
b. Dependent Variable: Enterprise Risk Management \\
Sumber: Data diolah dari SPSS 21 \\
Data ini sudah melalui tahap outlier
\end{tabular}

Dari tabel 14 diketahui bahwa nilai Durbin-Watson (DW) diperoleh sebesar 1,503. Dimana angka Durbin-Watson (DW) berada diantara -2 dan +2 , hal ini menunjukkan bahwa antara data tahun 2013, 2014, dan 2015 untuk variabel Dewan Komisaris, Leverage, dan Struktur Kepemilikan tidak saling berhubungan atau tidak terkait antara tahun sekarang dengan tahun sebelumnya sehingga model regresi dalam penelitian ini tidak terjadi autokorelasi.

\section{Uji Heteroskedastisitas}

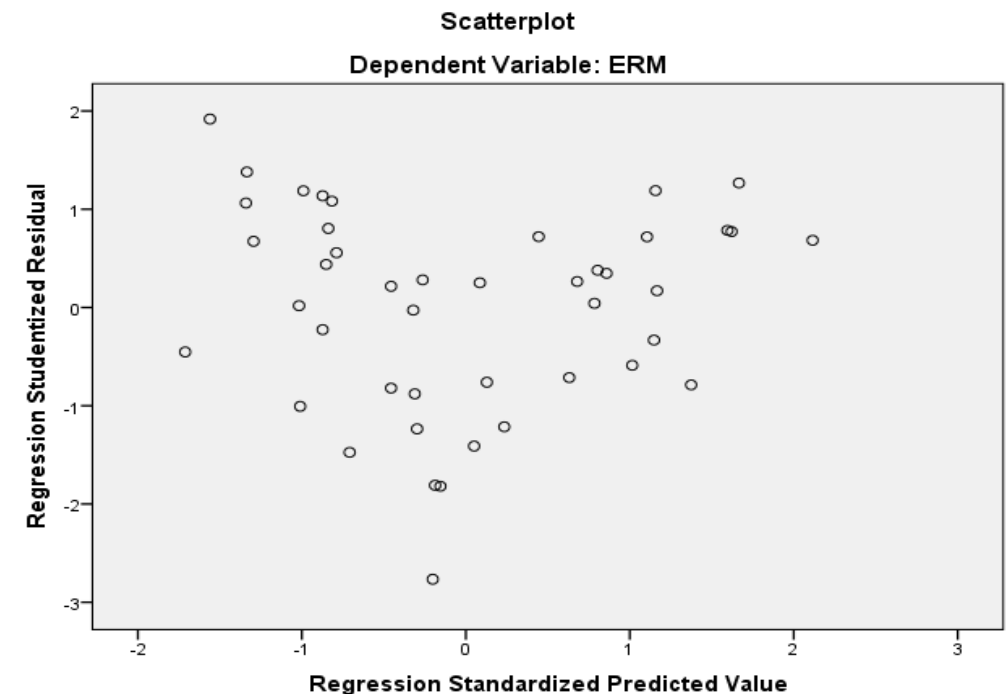

Sumber: Data diolah dari SPSS 21

Data ini sudah melalui tahap outlier

Gambar 5. Hasil Uji Heteroskedastisidas

Berdasarkan gambar 5 ditas untuk hasil pengujian heteroskedastisitas pada pengujian terhadap 44 data menunjukan bahwa seluruh variabel sudah tidak teridentifikasi adanya heteroskedastisitas yang ditunjukkan dengan tidak adanya pola yang jelas, serta titik-titik menyebar acak di atas dan dibawah pada angka 0 pada sumbu Y dalam grafik scatterplot. Hal ini berarti bahwa nilai data telah bebas dari heteroskedastisitas dan model regresi layak di pakai untuk memprediksi variabel dependen (Pengungkapan Enterprise Risk Management) berdasarkan masukan sejumlah variabel independen (Dewan Komisaris, Leverage, Struktur Kepemilikan). 
Uji Hipotesis

Uji Simultan (Uji F)

Tabel 15. Hasil Uji Simultan

\begin{tabular}{|c|c|c|c|c|c|c|}
\hline \multicolumn{7}{|c|}{ ANOVA $^{a}$} \\
\hline Model & & $\begin{array}{l}\text { Sum of } \\
\text { Squares }\end{array}$ & & $\begin{array}{c}\text { Mean } \\
\text { Square }\end{array}$ & $F$ & Sig. \\
\hline \multirow{3}{*}{1} & Regression & .039 & 3 & .013 & 4.006 & $.014^{\mathrm{b}}$ \\
\hline & Residual & .130 & 40 & .003 & & \\
\hline & Total & .169 & 43 & & & \\
\hline
\end{tabular}

a. Dependent Variable: Enterprise Risk Management

b. Predictors: (Constant), Struktur Kepemilikan, Leverage, Dewan Komisaris

Sumber: Data diolah dari SPSS 21

Data ini sudah melalui tahap outlier

Dari tabel 15 di atas, dengan menggunakan tabel distribusi $\mathrm{F}$ dengan taraf signifikansi 0.05 maka diperoleh Ftabel sebesar 2,84 dari hasil tersebut dapat dilihat bahwa Fhitung 4,006 $>$ Ftabel 2,84 dengan tingkat signifikan $0,014<0.05$. Hal ini berarti bahwa $\mathrm{H}_{0}$ ditolak dan $\mathrm{H}_{\mathrm{a}}$ diterima sehingga dapat disimpulkan bahwa Dewan Komisaris, Leverage, dan Struktur Kepemilikan secara bersama - sama (simultan) mempunyai pengaruh yang signifikan terhadap Pengungkapan Enterprise Risk Management.

\section{Uji Parsial (Uji t)}

Tabel 16. Hasil Uji Parsial

\begin{tabular}{|c|c|c|c|}
\hline \multicolumn{4}{|c|}{ Coefficients $^{a}$} \\
\hline & Model & $t$ & Sig. \\
\hline \multirow{4}{*}{1} & $($ Constant $)$ & 3.783 & .001 \\
\hline & Dewan Komisaris & 2.898 & .006 \\
\hline & Leverage & -1.034 & .307 \\
\hline & $\begin{array}{l}\text { Struktur } \\
\text { Kepemilikan }\end{array}$ & -.564 & .576 \\
\hline
\end{tabular}

a. Dependent Variable: Enterprise Risk Management

Sumber: Data diolah dari SPSS 21

Data ini sudah melalui tahap outlier

Dari tabel 16. di atas dapat diketahui bahwa variabel independen Dewan Komisaris memiliki $t_{\text {hitung }} 2,898>t_{\text {tabel }} 2,0210$ dengan nilai signifikansi sebesar $0,006<$ 0,05. Hal ini berarti Ho ditolak dan Ha diterima sehingga dapat disimpulkan bahwa variabel Dewan Komisaris memiliki pengaruh yang signifikan terhadap Pengungkapan Enterprise Risk Management.

Variabel independen Leverage memiliki $t_{\text {hitung }}-1,034<\mathrm{t}_{\text {tabel }} 2,0210$ dengan nilai signifiknasi sebesar 0,307 >0,05. Hal ini berarti Ho diterima dan Ha ditolak sehingga dapat disimpulkan bahwa variabel Leverage tidak memiliki pengaruh yang signifikan terhadap Pengungkapan Enterprisde Risk Management.

Variabel independen Struktur Kepemilikan memiliki $t_{\text {hitung }}-1,564<t_{\text {tabel }} 2,0210$ dengan nilai signifikansi $0,576>0,05$. Hal ini berarti Ho diterima dan Ha ditolak 
sehingga dapat disimpulkan bahwa variabel Struktur Kepemilikan tidak memiliki pengaruh yang signifikan terhadap Pengungkapan Enterprise Risk Management.

\section{Uji Koefisien Determinasi (R2)}

Tabel 17. Hasil Uji Koefisien Determinasi

\begin{tabular}{ccc}
\multicolumn{3}{c}{ Model Summary $^{b}$} \\
\hline Model & $R$ Square & Adjusted $R$ Square \\
\hline 1 & .231 & .173 \\
\hline
\end{tabular}

a. Predictors: (Constant), Struktur Kepemilikan, Leverage, Dewan Komisaris

b. Dependent Variable: Enterprise Risk Management

Sumber: Data diolah dari SPSS 21

Data ini sudah melalui tahap outlier

Dari tabel 17 diatas, menunjukan bahwa nilai Adjusted $R$ Square adalah sebesar 0,173 atau $17,30 \%$. Hal ini menunjukkan bahwa presentase kemampuan variabel independen yaitu Dewan Komisaris, Leverage, dan Sruktur Kepemilikan dalam menjelaskan variabel dependen yaitu Pengungkapan Enterprise Risk Management adalah sebesar $17,30 \%$, sedangkan sisanya sebesar $82,70 \%$ dijelaskan oleh variabel lain seperti Komisaris Independen, Reputasi Auditor, Risk Management Committee dan Ukuran Perusahaan.

\section{Pembahasan}

Berdasarkan hasil analisis yang telah dilakukan pada variabel independen yaitu Dewan Komisaris, Leverage, dan Struktur Kepemilikan terhadap variabel dependen yaitu Pengungkapan Enterprise Risk Management (ERM) secara simultan menunjukkan bahwa Fhitung 4,006 $>$ Ftabel 2,84 dengan tingkat signifikan 0,014 $<0,05$ maka dapat disimpulkan bahwa secara bersama-sama (simultan) variabel Dewan Komisaris, Leverage, dan Struktur Kepemilikan memiliki pengaruh yang signifikan terhadap Pengungkapan Enterprise Risk Management (ERM).

Dewan Komisaris berpengaruh signifikan terhadap Pengungkapan Enterprise Risk Management. Anggota dewan komisaris menambah peluang untuk saling bertukar informasi dan keahlian guna memberikan pengawasan yang efektif mengenai manajemen risiko perusahaan, sehingga dapat meningkatkan kualitas Enterprise Risk Management. Hasil penelitian variabel independen Dewan Komisaris mendukung penelitian sebelumnya yaitu Jatiningrum dan Fauzi (2012) serta penelitian Husaini, dkk (2013) yang menyatakan bahwa Dewan Komisaris berpengaruh signifikan terhadap Pengungkapan Enterprise Risk Management.

Leverage berpengaruh tidak signifikan terhadap pengungkapan Enterprise Risk Management. Hal ini dapat disebabkan karena tingkat Leverage yang tinggi menandakan bahwa perusahaan mengalami kesulitan dalam melunasi hutang serta bunganya. Oleh karena itu, perusahaan cenderung hati-hati dalam melakukan aktivitasnya sehingga perusahaan berusaha untuk mengurangi aktivitas yang sifatnya tidak optimal. Hasil penelitian variabel independen Leverage mendukung penelitian sebelumnya yang dilakukan oleh Syifa (2013) yang menyatakan bahwa Leverage berpengaruh tidak signifikan terhadap pengungkapan Enterprise Risk Management. 
Struktur Kepemilikan berpengaruh tidak signifikan terhadap Pengungkapan Enterprise Risk Managemnt. Hal ini dapat disebabkan karena perusahaan yang memiliki Struktur Kepemilikan yang terkonsentrasi menimbulkan kegiatan pengawasan secara optimal yang dilakukan oleh pemegang saham terbesar terhadap kinerja manajemen perusahaan tempat mereka berinvestasi karena dapat mengendalikan perilaku manajemen dalam memberikan standar kinerja manajemen yang tinggi. Hal tersebut dapat mengurangi risiko yang dihadapi perusahaan. Hasil penelitian ini konsisten dengan penelitian yang dilakukan oleh Ashuri et al., (2014) yang menyatakan bahwa

Struktur Kepemilikan tidak memiliki pengaruh yang signifikan terhadap Pengungkapkan Enterprise Risk Management.

\section{SIMPULAN}

Berdasarkan hasil penelitian yang telah dilakukan untuk menguji pengaruh Dewan Komisaris, Leverage, dan Struktur Kepemilikan terhadap Pengungkapan Enterprise Risk Management pada perusahaan perbankan yang terdaftar di Bursa Efek Indonesia (BEI) pada periode 2013 sampai dengan 2015.

Berdasarkan hasil penelitian yang telah dilakukan serta pembahasan yang telah diuraikan pada bab-bab sebelumnya, maka dapat diambil kesimpulan sebagai berikut:

a. Secara simultan diperoleh hasil bahwa Dewan Komisaris, Leverage, dan Struktur Kepemilikan memiliki pengaruh yang signifikan terhadap Pengungkapan Enterprise Risk Management.

b. Secara individual (parsial) diperoleh bahwa variabel independen yaitu Dewan Komisaris berpengaruh signifikan terhadap Pengungkapan Enterprise Risk Management, sehingga dapat disimpulkan bahwa hipotesis pertama $\left(\mathrm{H}_{1}\right)$ diterima. Variabel independen kedua yaitu Leverage tidak berpengaruh signifikan terhadap Pengungkapan Enterprise Risk Management, sehingga dapat disimpulkan bahwa hipotesis kedua $\left(\mathrm{H}_{2}\right)$ ditolak. Variabel independen ketiga yaitu Struktur Kepemilikan tidak berpengaruh signifikan terhadap Pengungkapan Enterprise Risk Management, sehingga dapat disimpulkan bahwa hipotesis ketiga $\left(\mathrm{H}_{3}\right)$ ditolak.

c. Melalui uji koefisien determinasi menunjukkan bahwa nilai Adjusted $R$ Square sebesar 0,173 atau 17,30\%. Hal ini menunjukkan bahwa 17,30\% Pengungkapan Enterprise Risk Management dapat dijelaskan oleh variabel Dewan Komisaris, Leverage, dan Struktur Kepemilikan sedangkan sisanya sebesar 82,70\% Pengungkapan Enterprise Risk Management dijelaskan oleh variabel lain seperti Chief Risk Officer, Reputasi Auditor, Risk Management Committee, dan Ukuran Perusahaan.

\section{Saran}

Berdasarkan hasil analisis dan kesimpulan yang telah diuraikan, maka saran yang dapat diberikan adalah sebagai berikut:

a. Bagi peneliti selanjutnya

Penelitian selanjutnya dapat menggunakan proksi sampel lain untuk menggambarkan Enterprise Risk Management pada sektor perusahaan lain. Selain itu, penelitian selanjutnya juga dapat menggunakan data primer berupa survey dalam bentuk kuisioner agar data yang dihasilkan lebih akurat.

b. Bagi manajemen perusahaan

Manajemen perusahaan disarankan untuk mengungkapkan informasi secara luas dan jelas agar para pengguna laporan keuangan dapat lebih memahami informasi yang 
terdapat di dalam laporan keuangan dan laporan tahunan yang disajikan serta lebih memperhatikan manajemen risiko perusahaan serta pengendalian internal perusahaan dalam mengungkapkan berbagai risiko yang terjadi baik untuk mematuhi peraturan yang telah ditetapkan pemerintah dan pengungkapan risiko lainnya yang dianggap penting untuk bisa menjadi bahan pertimbangan serta untuk mewujudkan good corporate governance

c. Bagi investor

Bagi investor disarankan untuk lebih memperhatikan manajemen risiko yang diungkapkan perusahaan. Hal ini dapat dijadikan sebagai bahan petimbangan dalam mengambil keputusan dalam berinvestasi

\section{DAFTAR PUSTAKA}

,Undang - Undang Republik Indonesia Nomor 40 Tahun 2007 tentang Perseroan Terbatas

Andarini, P.,\& Januarti, I. (2010). Hubungan Karakteristik Dewan Komisaris dan Perusahaan Terhadap Pengungkapan Risk Management Committee (RMC) pada Perusahaan go public indonesia.Simposium Nasional Akuntansi XIII Purwokerto, hlm. 1-27

Anggiawan, F. (2014). Okezone.com. 4 Tersangka Kasus BSM Dilimpahkan ke Kejaksaan. $\quad$ Diakses $19 \quad$ Februari $2014 . \quad$ Dari http://news.okezone.com/read/2014/02/18/339/943005/4-tersangka-kasus-bsmdilimpahkan-ke-kejaksaan

Ashuri, N.N., \& Asadpour, A.A. (2014).The impact of board composition, audit fees, and ownership concentration on risk management of listed companies in tehran exchange .Academic Journal of Accounting and Economic Researches, Vol. 3 No.1 Page 1-9.

Carolin, A.I., \& Wardhani, R. (2011). The Effect of Accounting Disclosure, Concentrated Ownership, and Accounting Harmonization to Earnings Quality: The Case of Asia Pacific. Simposium Nasional Akuntansi XIV Aceh. 21-22 Juli 2011 .

Committee of Sponsoring Organizations of the Treadway Commission (COSO). (2004). Enterprise Risk Management-Integrated Framework Executive Summary.Diakses $202016 . \quad$ September Dari http://www.coso.org/documents/coso_erm_executivesummary.pdf.

Effendi, M.A. (2016). The Power of Good Corporate Governance : Teori dan Implementasi. Edisi 2, Jakarta : Salemba Empat.

Ghozali, I. (2013). Aplikasi Analisis Multivariate Dengan Program IBM SPSS 2, Semarang : Universitas Diponegoro. 
Godfrey, J., Hodgson, A., Tarca, A., Hamilton, J., \& Holmes, S. (2010). Accounting Theory, United States of America: John Wiley \& Sons, Inc.

Gubernur Bank Indonesia, Peraturan Bank Indonesia Nomor 8/4/PBI/2006 tentang Pelaksanaan Good Corporate Governance.

Gubernur Bank Indonesia, Peraturan Bank Indonesia Nomor 11/25/PBI/2009 tentang Penerapan Manajemen Risiko Bagi Bank Umum.

Harahap, SS. (2013). Teori Akuntansi, Edisi Revisi 2011, Jakarta : RajaGrafindo Persada

Houston, F ., \& Brigham, F. (2011). Dasar - Dasar Management Keuangan, Edisi 11, Jakarta : Salemba Empat.

Husaini, S., Fadli, A \& Aisyah. (2013). Corporate Governance and Enterprise Risk Management : An Empirica Evidence from The Unique Two-Tier Boards System of Indonesia Public Listed Companies.Proceedings of World Business and Social Science Research Conference.

Jatiningrum \& Fauzi. Pengaruh Corporate Governance dan Konsentrasi Kepemilikan pada Pengungkapan Enterprise Risk Management. Di akses 10 Maret 2014. Dari http://feakuntansi.unila.ac.id/2010/download/prosiding-pdf/2.pdf

Kasmir.(2011). Analisis Laporan Keuangan. Edisi 4, Jakarta : PT. Rajafindo Persada.

Ketua Badan Pengawas Pasar Modal dan Lembaga Keuangan, Keputusan ketua badan pengawas pasar modal dan lembaga keuangan nomor Kep-11/PM/1997 tentang Pedoman Mengenai Bentuk Dan Isi Pernyataan Pendaftaran Dalam Rangka Penawaran Umum Oleh Perusahaan Menengah atau Kecil

Ketua Badan Pengawas Pasar Modal dan Lembaga Keuangan, Keputusan ketua badan pengawas pasar modal dan lembaga keuangan nomor Kep-431/BL/2012 tentang penyampaian laporan tahunan emiten atau perusahaan publik

Kumalasari, M., Subowo., \&Anisykurillah, I. (2014). Faktor - faktor Yang Berpengaruh Terhadap Luas Pengungkapan Manajemen Risiko. Accounting Analysis Journal. Vol.3 No.1.

Lam, J. (2007). Enterprise Risk Management Panduan Komprehensif bagi Direksi, Komisaris, dan Profesional Risiko, Jakarta: PT. Ray Indonesia.

Meizaroh \& Lucyanda, J. (2011). Pengaruh Corporate Governance dan Konsentrasi Kepemilikan pada Pengungkapan Enterprice Risk Management. Simposium Nasional Akuntansi XIV Aceh. 21-22 Juli 2011. hlm.1-30.

Onder, S., \& Ergin, H. (2012). Determiners of Enterprise Risk Management applications in turkey : an empirical study with logistic regression model on the 
companies included in ise (istanbul stock exchange). BEH - Business and Economic Horozons. Vol.7 No. 1. Page 19-26.

Peraturan Menteri Negara Badan Usaha Milik Negara Nomor : PER-01/MBU/2011 Tentang Penerapan Tata Kelola Perusahaan Yang Baik (Good Corporate Governance) Pada Bank Usaha Milik Negara

Prayoga, EB \& Amilia, LS. (2013). Pengaruh Struktur Kepemilikan dan Ukuran Perusahaan Terhadap Pengungkapan Manajemen Risiko.Jurnal Akuntansi \& Keuangan. Vol. 4 No. 1. hlm. 1 - 19.

Sari F, J. (2013). Implementasi Enterprise Risk Management pada Perusahaan Manufaktur Indonesia Lag.Accounting Analysis Journal. Vol.2 No.2.

Sunyoto, D. (2011). Analisis Regresi dan Uji Hipotesis, Cetakan Pertama. Yogyakarta: CAPS

Syifa, L. (2013). Determinan Pengungkapan Enterprise Risk Management Pada Perusahaan Manufaktur di Indonesia. Accounting Analysis Journal.Vol.2 No.3. hlm. 286-294.

Syukur, M. (2014). Liputan6.com. Kredit Fiktif 3 Eks Pejabat BNI Pekanbaru di Vonis 9 Tahun Bui. Diakses 12 September 2014. Dari http://news.liputan6.com/read/2104642/kredit-fiktif-3-eks-pejabat-bni pekanbarudivonis-9-tahun-bui 